\title{
Fourth Sister Zhang Creates Havoc in the Eastern Capital
}

\section{Citation}

Idema, Wilt Lukas. 2012. "Fourth Sister Zhang Creates Havoc in the Eastern Capital."

CHINOPERL: Journal of Chinese Oral and Performing Literature 31 (1): 37-112.

\section{Published Version}

doi:10.1179/chi.2012.31.1.37

\section{Permanent link}

http://nrs.harvard.edu/urn-3:HUL.InstRepos:13792760

\section{Terms of Use}

This article was downloaded from Harvard University's DASH repository, and is made available under the terms and conditions applicable to Open Access Policy Articles, as set forth at http:// nrs.harvard.edu/urn-3:HUL.InstRepos:dash.current.terms-of-use\#OAP

\section{Share Your Story}

The Harvard community has made this article openly available.

Please share how this access benefits you. Submit a story.

Accessibility 
Draft

Fourth Sister Zhang Creates Havoc in the Eastern Capital

Wilt L. Idema, Harvard University

The basic story of Fourth Sister Zhang Creates Havoc in the Eastern Capital (Zhang Sijie danao Dongjing 張四姐大閙東京) is widely known in China and has been adapted, under a bewildering variety of titles, in many local genres of drama and storytelling. ${ }^{1}$ The earliest record of this story is found in the notice devoted to the lost chuanqi 傳奇 play A Heavenly Bond (Tianyuan ji 天緣記) in the eighteenth-century Quhai zongmu tiyao 曲海總目題要 (Annotated Bibliography of the Sea of Plays). ${ }^{2}$ This notice may be translated as follows:

A Heavenly Bond.

It is [also] called Displaying Flowers, Fourth Sister Zhang Longs for the Mortal World (Baihua Zhang Sijie sifan 擺花張四姐思凡). It is based on a drum ballad ( $g u c i$ 鼓詞) and is absurd and fantastic. But in its disposition of characters and armies, and its description of banners and weapons, fights and confrontations, it is ingenious and original, enjoyable and amazing, so it is well worth watching.

Duan Chengshi 段成式 [ -863] in his Nuogao ji 諾泉記 [Record of Nuogao] writes: “Old Man Heaven is called Zhang Jian 張堅; his style is Cike 刺渴 and he hails from Yuyang 漁陽." 3 So it is not that there is no reason to say that a daughter of Heaven is surnamed Zhang.

The play may be summarized as follows: Fourth Sister Zhang is a daughter of the Jade Emperor and the Queen-Mother. ${ }^{4}$ She has six elder and younger sisters and lives in the Dipper and Buffalo Palace. In the days of the Humane Ancestor

\footnotetext{
${ }^{1}$ Yamamoto Noriko 山本範子, “Araburu senjo Zhang Sijie: Kasei hōkan 'Zhang Sijie danao Dongjing' o chūshin ni” 荒ぶる仙女張四姐: 河西宝巻 “張四姐大閙東京” 中心に (The Insolent Female Immortal, Fourth Sister Zhang: Centering on the Hexi "precious scroll” Fourth Sister Zhang Creates Havoc in the Eastern Capital), Chügoku gakushi 中國學志 19 (2004):23-41, p. 24. "Hexi” (West of the Yellow River) refers to the Western part of the modern province of Gansu.

${ }^{2}$ Du Yingtao 杜穎陶, ed., Quhai zongmu tiyao 曲海總目題要 (Beijing: Renmin wenxue, 1959), juan 40, pp. 1859-60. This work was compiled in the first half of the eighteenth century. We do not know the names of the compilers and the version we have today is not complete.

${ }^{3}$ On Duan Chengshi's Nuogao ji, a section of his Youyang zazu 酉陽雜沮 (Miscellaneous Morsels from the South Slope of You Mountain), see Carrie L. Reed, A Tang Miscellany: An Introduction to Youyang zazu (New York: Peter Lang, 2001). For a full translation of this item, see Duan Chengshi, Chinese Chronicles of the Strange: The “Nuogao ji," Carrie E. Reed, tr. (New York: Peter Lang, 2003), p. 32. ${ }^{4}$ At this point a small-character double-column note warns against taking this figure as the Queen Mother of the West (Xiwangmu 西王母).
} 
[Renzong] of the Song dynasty a certain Cui Wenrui 崔文瑞 of the Eastern Capital, an impoverished gentleman, lives in an abandoned temple where he looks after his mother. Fourth Sister and Cui have an immortal affinity, so she descends [to the mortal world] and marries him. Cui suddenly becomes extremely wealthy; his gold and pearls and precious goods cannot be counted. A rich man, Squire Wang [Wang yuanwai 王員外], falsely accuses Cui of theft. Commander Zhang 張 accepts Wang's bribes and questions Cui under torture. Fourth Sister then enters the jail to free Cui; she sets all prisoners free and kills Squire Wang. When the commander reports this to the throne, Bao Zheng 包拯 is dispatched to arrest Fourth Sister, but he too is captured. Upon his release he proposes to the emperor to have her subdued by the Generals of the Yang family. But when Yang Wenguang 楊文廣 and Huyan Qing 呼延慶 fight with her, they are both defeated and locked in her soul-catching bottle. [The court] next deploys the five women generals [of the Yang family] Mu Guiying 穆桂英, Third Sister Li [Li Sanniang 李三娘], Princess Chacha [Chacha gongzhu 查查公主], Miss Lanfeng [Lanfeng xiaojie 藍峰小姐], and Princess Prettier than a Flower [Saihua gongzhu 賽花公 主], who all can ride on the mist and rise on the clouds, and who can make dust swirl and stones fly! But when they engage her in battle and manifest their supernatural powers they too are all defeated and locked in the soul-catching bottle. Bao Zheng enters hell and also visits the Buddha lands for a comprehensive investigation but nowhere can he ascertain the origins of Fourth Sister. He then arrives at the Southern Gate of Heaven and pays a call on the Old Lord [Laozi], who takes him to memorialize [the matter] to the Jade Emperor. Only when a personnel count is conducted in the Dipper and Buffalo Palace is it discovered that three days ago Fourth Sister descended to the mortal world. [The Jade emperor] thereupon dispatches a team of the Fire Dragon 火龍, Nezha 哪吒 and the Great Sage Equal to Heaven [Sun Wukong 孫悟空] to set off together, and orders them to bring her back to the palace. But when they engage her in battle, they too are utterly defeated. When the case is reported to the QueenMother she orders her [Fourth Sister's] six immortal sisters to talk her around and tell her to report to the Jade Emperor. Fourth Sister then has Wenrui and his mother ascend to the sky together with her and both of them attain the fruit of immortality.

The three heavenly treasures that Fourth Sister had stolen and uses are the heaven -piercing cap [zuantian mao 鑽天帽] - if you wear it you can freely move through all thirty-three heavens; the earth-entering shoes [rudixie 入地鞋]—if you wear those you can freely come and go through the eighteen hells; and the soul-catching bottle [shehun ping 攝魂瓶] - if you use it, all celestial gods and heavenly generals are sucked inside! The story very much resembles Journey to the West [Xiyou ji 西游記] and Creation of the Gods [Fengshen yanyi 封神演義]. But in each scene the immortal maiden appears in full armor, and this is something which is not found in other plays. 
It will be clear from the summary presented here that the story of Fourth Sister Zhang Creating Havoc in the Eastern Capital in its modern shape must have appeared very late, at a stage when the legends of Judge Bao, ${ }^{5}$ the Generals of the Yang family, and many others had already been fully developed. But the origin of the tale can be traced a long way back. The editorial notes following this entry in the Quhai zongmu tiyao draw attention to the Tang-dynasty tale "Guo Han 郭翰," in which the student of that name receives nightly visits from the Weaving Maiden (who is often identified as the eldest of the seven celestial sisters). ${ }^{6}$ The same notes also mention the tale of Wei Andao 韋安道, whose lover Lady Earth (Houtu furen 后土夫人) defeats all gods and demons dispatched against her. ${ }^{7}$ The most direct source for the story of Fourth Sister Zhang, however, is probably the Tang dynasty tale “Student Cui” (Cui shusheng 崔書生) from Niu Sengru's 牛僧孺 (780-848) Xuanguai lu 玄怪錄 (Record of Dark and Strange Things). ${ }^{8}$ In this story Student Cui draws the attention of a beautiful maiden because of the flowers he grows and makes her his wife. But his mother grows suspicious because of her extraordinary beauty, whereupon she decides to leave. The present she gives him at her departure, however, makes his fortune as he is able to sell it for millions to a foreign monk who also informs him that his wife was none other than the third daughter of the Queen-Mother of the West. In the modern versions of the legend of Fourth Sister Zhang the immortal maiden also makes her husband a very wealthy man, but already during their married life. One of the magical objects she brings with her from heaven in many versions of the legend is a "tree" that produces cash when shaken (yaoqian shu 搖錢樹). Some of these versions are named after this object. ${ }^{9}$

Tang students need little encouragement to sleep with the immortal maidens who offer themselves to them, but we also find examples of more reluctant lovers. In later centuries we encounter the motif of the amorous maiden who has to use all her magical powers in order to overcome the resistance of the young man she has set her mind on. If her actions are caused by lust and result in the birth of a baby, she will later be

\footnotetext{
${ }^{5}$ Yamamoto, "Araburu senjo," pp. 29-36, discusses at length the image of the fallible Judge Bao that is encountered in this tale.

${ }^{6}$ For this story, see Li Fang 李昉, ed., Taiping guangji 太平廣記 (Broad Gleanings of the Taiping Era; Beijing: Zhonghua shuju, 1961), juan 68, pp. 420-21. The Taiping Guangji quotes the story from the Lingguai ji 靈怪集 (Record of Mysterious Miracles) by Zhang Jian 張薦 (774-804). For a recent English translation of this tale see Wilt L. Idema, Filial Piety and Its Divine Rewards: The Legend of Dong Yong and Weaving Maiden with Related Texts (Indianapolis: Hackett Publishing, 2009), pp. 83-86.

${ }^{7}$ Li Fang, ed., Taiping guangji, juan 299, pp. 2375-79. The Taiping guangji lists the Yiwen $l u$ 異聞錄 (A Record of Strange Things Heard) as its source.

${ }^{8}$ Taiping guangji, juan 63, pp. 392-394. See also Niu Sengru 牛僧孺 and Li Fuyan 李復言, Xuanguai lu, Xu Xuanguai lu 玄怪錄, 續玄怪錄 (Record of Dark and Strange Things and A Continuation of Record of Dark and Strange Things), Jiang Yun 姜雲 and Song Ping 宋平, annot.( Shanghai: Shanghai guji, 1985), pp. 43-46.

${ }^{9}$ On the "real" yaoqian shu and the role of such items in popular literature, see Jiang Yuxiang 江玉祥, “Guanyu kaogu chutu de 'yaoqian shu' yanjiu zhong de jige wenti” 關於考古出土的“搖錢樹” 研究中的 幾個問題 (Several Questions Concerning the Study of Archaeologically-Discovered "Shake-Out Money Trees”), Sichuan wenwu 四川文物 (Sichuan Cultural Objects) 2000.4: 10-13.
} 
imprisoned and it will be up to her son to eventually liberate her. ${ }^{10}$ If the immortal maiden is attracted to the young man not because of his handsome features but because of his high moral standards, preferably his great filial piety, she will be able to escape being jailed in the prisons of earth, but she still will meet with stiff opposition. Instead of battles that result in her capture and her son's battles to free her, we now have battles waged by our heroine to save her husband. In her loyalty to her filial husband the wife defeats all mortal and celestial opponents and eventually is able to take her husband and his mother with her to heaven where they will all enjoy eternal bliss. ${ }^{11}$ The immortal maiden is only completely free of blame if she has been ordered to descend to the mortal world, as in the legend of Dong Yong 董永. ${ }^{12}$

The version of the story of Fourth Sister Zhang Creating Havoc in the Eastern Capital translated here is a precious scroll (baojuan 寶卷) ${ }^{13}$ from Western Gansu. In the 1980s it became clear that local traditions of precious scroll recitation in many of the remote areas of Western Gansu had survived the Cultural Revolution rather well. ${ }^{14}$ Few of the scholars who have since published on the subject have failed to mention the popularity of the story of Fourth Sister Zhang, which circulated in a number of versions.

\footnotetext{
${ }^{10}$ This is the outline of the legend of Chenxiang 沉香. For a study of this legend, see Glen Dudbridge, "The Goddess Hua-yüeh San-niang and the Cantonese Ballad Ch'en-hsiang T'ai-tzu," Hanxue yanjiu 漢學研究 (Chinese Studies) 8.1 (1990): 627-46. For the impact of this pattern on other tales of sons saving their mother from imprisonment, see Wilt L. Idema, The White Snake and Her Son: A Translation of The Precious Scroll of Thunder Peak with Related Texts (Indianapolis: Hackett Publishing, 2009), pp. xvi-xxi. For a full translation of the Precious Scroll of Chenxiang (Chenxiang baojuan 沉箱寶卷) by Wilt L. Idema, see Victor H. Mair and Mark Bender, eds., The Columbia Anthology of Chinese Folk and Popular Literature (New York: Columbia University Press, 2011), pp. 380-405.

${ }^{11}$ Yamamoto, "Araburu senjo," p. 26, notes that in some genres of regional opera Fourth Sister Zhang is eventually imprisoned by Yang Erlang 楊二郎, and interprets this as a sign of the influence of the legend of Chenxiang.

${ }^{12}$ For the legend of Dong Yong see Wilt L. Idema, Filial Piety and Its Divine Reward and the Chinese scholarship listed in the bibliography.

${ }^{13}$ Precious scrolls can be traced back at least to the Yuan dynasty. The earliest precious scrolls are Buddhist prosimetric narratives and ritual texts. From the Ming dynasty onward the term was also used in reference to sectarian scriptures. From the eighteenth century onward the genre broadened its subject matter and could include almost any traditional story but continued to have religious functions nonetheless. See Daniel L. Overmyer, Precious Volumes: An Introduction to Chinese Sectarian Scriptures from the Sixteenth and Seventeenth Centuries (Cambridge MA: Harvard University Asia Center, 1999. See also Wilt L. Idema, "Prosimetric and Verse Narrative," in Kang-i Sun Chang and Stephen Owen, eds., The Cambridge History of Chinese Literature, 2 Vols. (Cambridge: Cambridge University Press, 2010), 2: 35054 and 399-401. For an introduction to English-language scholarship on baojuan, see my research note on this topic in this volume.

${ }^{14}$ For a concise summary of Chinese scholarship in this field, see Xun Fang 邭芳, “Hexi baojuan yanjiu huigu” 河西賈卷研究回顧 (A Retrospective Look at the Scholarship on Hexi Precious Scrolls), Dang'an (Archives) 2010.1: 35-37. For a list of published and as yet unpublished precious scrolls from Western Gansu, see Wang Wenren 王文仁, “Hexi baojuan zongmu diaocha” 河西寶卷總目調査 (A Survey and Bibliography of Hexi Precious Scrolls), Minsu wenhua 民俗文化 (Folk Culture) 2010.12: 38-40. One of the earliest Western-language publications to draw attention to the precious scrolls of Western Gansu was Victor H. Mair, Painting and Performance: Chinese Picture Recitation and Its Indian Genesis (Honolulu: University of Hawai'i Press, 1988), pp. 9-13. See also Wei Chiao, "Folk Literature and Popular Beliefs in the Ho-hsi Corridor (Kansu Province)," in Minjan xinyang yu Zhongguo wenhua guoji yantao hui lunwen ji 民間信仰與中國文化國際研討會論文集 (Collected Essays from the International Conference on Folk Belief and Chinese Culture; Taipei: Hanxue yanjiu zhongxin, 1994), pp. 181-200.
} 
Fourth Sister Zhang is greatly praised for her daring in leaving heaven, her fidelity to her husband, and her brazen defiance of all earthly and heavenly authorities. ${ }^{15}$ This translation is based on the text included in one of the earliest monographs on this material, Fang Buhe 方步和, ed., Hexi baojuan zhenben jiaozhu yanjiu 河西寶卷眞本校註研究 (Studies and Collation and Annotation of Authentic Copies of Hexi Precious Scrolls) of 1992. ${ }^{16}$ The text is described as having been “collected” (souji 搜集) by a Feng Qiang 馮 強 from a copy (or copies) made (tengchao 謄抄) by a Wang Bin 王斌, Cai Zhengxue 蔡 正學, and Xu Zhude 徐祝徳 of the village of Zhangyibao 張義堡 in Wuwei 武威. ${ }^{17} \mathrm{~A}$ different text is included in Jiuquan baojuan (shangbian) 酒泉寶卷 (上編) (Jiuquan Precious Scrolls [First Collection]). ${ }^{18}$ This latter text is based on a manuscript made in 1943 by the local peasant Tian Shanghai 田上海 in Dongdong 東洞 Village in Jiuquan. The story line in both texts is roughly the same, but whereas the second text primarily relies on seven-syllable lines in its verse sections, the text translated here mostly employs ten-syllable lines and would appear to be somewhat less literary in character. In the main body of the narrative the sections in ten-syllable verse are followed by a short passage in prose, which in turn is concluded by a couplet or quatrain. ${ }^{19}$

As noted above, in the Tang dynasty classical story "Student Cui," it was Third Sister who became the lover of Cui Wenrui. There also exists a Gansu precious scroll in which Third Sister is the protagonist rather than Fourth Sister. ${ }^{20}$ But in that version Third Sister's longing for the mortal world is inspired by Fourth Sister's adventures. She goes to Guanzhou 貫州, where she marries Yan Tianyou 閻天佑. When her husband is

\footnotetext{
${ }^{15}$ See for instance Liu Yonghong 劉永紅, “Eryuan duili yu kanghuan: Hexi bojuan zhong de nüxing renlei xue jiedu” 二元對立與狂歡: 河西寶卷中的女性人類學解讀 (Dualism and Ecstasy: An Anthropological Reading of the Female Characters in Hexi Precious Scrolls), Qinghai shifan daxue minzu xиеуиап xиebao 青海師範大學民族學院學報 (Journal of Qinghai Normal Ethnic Nationality College) 2011.5: 18-21.

${ }^{16}$ Lanzhou: Lanzhou daxue, 1992, pp. 127-164. This same text is also included in He Denghuan 何登焕 ed., Yongchang baojuan 永昌寶卷 (Yongchang Precious Scrolls; Yongchang: Yongchangxian wenhua ju, 2003), pp. 77-96; Xu Yongcheng 徐永成, ed., Jin Zhangye minjian baojuan 金張掖民間寶卷 (Golden Zhangye Popular Precious Scrolls; Lanzhou: Gansu wenhua, 2007), pp. 41-59; and Zhang Xu 张旭, ed., Shandan baojuan 山丹寶卷 (Shandan Precious Scrolls; Lanzhou: Gansu wenhua, 2007), pp. 274-90.

${ }^{17}$ See the parenthetical note at the end of the text in Hexi baojuan zhenben jiaozhu yanjiu, pp. 159-60.

${ }^{18}$ Lanzhou: Gansu renmin, 1991, pp. 307-35. A revised version of this collection was included as the first volume in a more extensive set of three volumes, also called Jiuquan baojuan and published in 2001 by the Cultural Bureau (Wenhua guan 文化館) of the City of Jiuquan.

${ }^{19}$ Yamamoto, "Araburu senjo," p. 24, lists ten different titles used for baojuan versions of the Fourth Sister Zhang story. Besides the Jiuquan version mentioned above, two other baojuan versions of the Fourth Sister Zhang story using seven-syllable verse have been reproduced. A manuscript titled Nao Dongjing 鬧東京 (Creating Havoc in the Eastern Capital) copied by a “Guanqun” 冠群 in a dingsi 丁巳 year (1857? 1917?) is photographically reproduced in Baojuan chuji 寶卷初集 (First Collection of Precious Scrolls), 40 vols. (Taiyuan: Shanxi renmin, 1994), 35: 379-470 and in Minjian baojuan 民間寶卷 (Popular Precious Scrolls), 20 vols. (Hefei: Huangshan shushe, 2005), 20: 301-24, and a manuscript titled Tianxian baojuan 天仙寶卷 (Precious Scroll of the Heavenly Immortal) copied by Xu Jinzhai 許錦齋 in 1905 is photographically reproduced in the same volume, pp. 325-50 (divided in two juan, see the cover of the second juan, p. 337, for the date).

${ }^{20}$ See, for instance, San shengu xiafan baojuan 三神姑下凡寶卷 (Precious Scroll of Third Sister Immortal Descending to the Mortal World), in Xu Yongcheng 徐永成, ed. Jin Zhangye minjian baojuan, pp. 147-61.
} 
arrested, she not only defeats all government troops sent against her, but also all heavenly deities, including Sun Wukong. In the end she returns to heaven with her husband. 


\section{Precious Scroll of Fourth Sister Zhang Creating Havoc in the Eastern Capital}

Now this precious scroll of Fourth Sister has been opened, May Her Majesty the Queen-Mother descend from heaven! May divine beings such as gods and dragons, filled with joy, Protect the common people, safeguard them from disaster! May you, good men and pious women seated on both sides, Prick up your ears to listen and remember this in your heart!

May each of you act in accordance with this precious scroll; Practice many good deeds and be free from evil in your heart: If you practice good deeds, you will be loved by all people; If you commit evil deeds, your body will be burned to cinders. So I have made this scroll that may bring a smile to your face, And leave it behind in this world for people's entertainment.

Now tell that this precious scroll took place during the reign of the Humane Emperor of the Song dynasty. In those days the winds and rains were moderate and timely, the state was prosperous and the people were settled. In the city of Bianliang, the Eastern Capital, there lived a student named Cui Wenrui. His father Squire Cui had been powerful and rich - his mules and horses formed herds, and he had plenty of gold and silver. But after his father passed away, the family had unfortunately been struck by lightning and their house and treasures had all been turned to ashes. Mother and son now had to rely on begging in order to survive, and at night they stayed in an old temple. Once the friends who had been so close to them in earlier days saw that Wenrui had been reduced to these circumstances, they promptly kept their distance.

${\text { (Ten-syllable tune })^{21}}^{21}$

Cui Wenrui

Was originally

A golden $\operatorname{lad}^{22}$ who had come down to earth;

When he had descended to this world,

He had become a student

His mother had been

Who made a living by selling his writing.

A daughter of the Wang family,

But now she was old and bereft of energy;

\footnotetext{
${ }^{21}$ Each of these lines has ten characters and scan into phrases of three, three, and four characters. To show this structure, they have been translated so that each line has three phrases.

${ }^{22}$ Golden lads (jintong 金童), together with jade girls (yunü 玉女) were attendants in heaven. There are many tales in which they are incarnated and fall in love with each other in the mortal world.
} 
Her eyes were hazy,

Her ears were deaf,

And she lacked the strength to move about.

So Cui Wenrui

Would each day

Beg for food going from street to street;

When he had begged a bowlful,

He would save the larger half

To offer up to his mother for her support.

Each and every day

He didn't even get

Half a bowl of rice or half a bowl of noodles;

Mother and son,

Bereft of food and clothes,

Found it hard to bear such hunger and cold!

Now tell that Wenrui supported his mother by his begging and suffered greatly in this way - but no more of this. Instead tell that the fourth daughter of His Majesty the Jade Emperor, who was called Fourth Sister Zhang, one day, when she was sitting in the Palace of Dipper and Buffalo, suddenly noticed a burst of evil ether rising up to heaven. When she computed its causes on her fingers, she realized that a golden lad was in trouble, serving out his punishment in the mortal world. Unconsciously her feelings were moved: "Why don't I borrow the "ocean-fixing" treasures ${ }^{23}$ of the Third Prince of the Dragon King of the Eastern Ocean? On the one hand, I can save that golden lad. On the other hand, I can become man and wife with him!" When she had reached this conclusion, she promptly descended to the mortal world and arrived in the Eastern Capital. Indeed:

Holding her hairpin of gold she displayed her magical powers:

The jade maiden wanted to become the wife of that golden lad.

Fourth Sister Zhang

Saw in the mortal realm

An ether of suffering that did not disperse,

So she borrowed treasures

And without any thought for herself

Descended from the heavenly palaces.

In the blink of an eye

She had quickly passed through

And within an hour

The three gates that guard heaven's entrance,

She had arrived

In the Eastern Capital Bianliang.

Upon her arrival

She promptly met

\footnotetext{
${ }^{23}$ Zhenhai bao 鎮海寶. The enormously heavy staff that Sun Wukong gets from the Dragon King is also referred to as such a treasure.
} 
Face to face with that student Cui Wenrui,

And softly said:

"Dear Mr. Cui

What makes you so worried and sad?"

Cui Wenrui

Then walked up to her

And turning the question around he said:

"I am a man

And you are a woman-

What is your reason for asking this question?"

Fourth Sister Zhang

Then began to speak

And again said "Dear Mr. Cui,

Where do you live?

Where are you from?

Tell me your background in detail!

What is your surname?

What is your own name?

Please tell it clearly to me.

What kind of event

Did you encounter

When Cui Wenrui

That you now make a living by begging?"

Had heard these words

He said to her: "Young lady,

I will for you

In great detail

Completely recount the facts.

Our home was here

In the Eastern Capital

In a little lane named after our family.

My father was

Squire Cui

A man advanced in years and bent by age;

My mother is

A daughter of the Wangs

A woman of wisdom and virtue.

Above me no elder brothers

Below me no younger brothers

I am the only child that was born to them.

Remembering back then

When my father was still alive

Our family was powerful and wealthy,

But upon his death

The house was struck by lightning:

Everything was completely burned to ashes! 
This left us

My mother and me

At a loss how to survive from day to day,

So I go out onto the streets

Begging for food to eat

To take care of my mother."

When Fourth Sister Zhang

Had heard these words

Tears gushed from her eyes like rain, And she cried out:

"Old man heaven

How can you so torture my darling!"

Now tell that Fourth Sister upon hearing this was awash in tears. She then asked Wenrui: "Do you have a wife?" Wenrui replied: "We are so poor! How could I be able to take a wife? And besides, who would be willing to live with me?" Fourth Sister said:

"There is something I want to tell you. Whether or not it works out, please don't be upset. Since you do not have a wife, if you do not despise my big feet and ugly face, I would be happy to become your wife. What, sir, do you think of that proposal?" Upon hearing this Wenrui promptly replied: "Young lady, I don't have a single furrow of land and not a single room to live in. My mother and I survive by begging, so how could I support a wife? This is absolutely impossible. Young lady, please leave me alone." Fourth daughter addressed him, smiling coldly, in the following words: "I treated you with completely pure intentions, but look how lacking in feeling is your response. In truth,

My sincere heart I placed in the bright moon,

But who knew the moon would end up in a ditch.

If you really are going to reject me, I will make it so that you will not be able to separate heaven from earth and will be unable to distinguish east from west, or north from south!" As she was speaking, all you could see was Fourth Sister move one finger, and Cui Wenrui immediately lost all consciousness.

Cui was unconscious for a while, and when he came to Fourth Sister Zhang had disappeared. Groping his way he then left the city to find his mother. But for no reason that he knew of, his whole body was racked by pain and his four limbs were bereft of strength, and he found it very difficult to go any further. Seeing an abandoned kiln in front of him he crawled inside to get some rest. But suddenly he remembered that his mother had not had any rice to eat the entire day and that he had no idea how she was doing, so involuntarily tears fell from his eyes. How heart-rending! Indeed:

Fourth Sister Zhang had put a spell on Cui Wenrui:

His body was so racked by pain-he found no peace.

Fourth Sister Zhang

Was in origin

A girl from the heavenly palace, 
And she scared

Cui Wenrui so much

That he had no idea of east or west.

His whole body was hurting

He lacked all strength

And found it impossible to move;

At a loss what to do

He could only

Lie down in a dilapidated kiln.

His old mother

In the old temple

Waited throughout the day:

From early morning

Till the setting sun

She did not see him come back.

So hungry that

She lacked all strength

Her eyes were hazy and her ears were deaf!

Who could have known

That Fourth Sister Zhang

Cui Wenrui

Had put a spell on her darling son?

Had clearly said

He was off to beg food for his mother;

Who could have known

That in the midst of calm

Threatening waves would swell up?

In such cold that

Old mother of his-

How could she possibly sleep!

When he thought about this

He who was her son

Felt extremely disconsolate indeed!

"If I had known

That she was not

I would not have

A girl from the mortal world,

Refused her offer

When she proposed this marriage.

Now she deliberately

Has arranged for me

To suffer these trials and ordeals,

But could it be

She'd want my mother

To really die of starvation?"

Mother longed for son 
Son longed for mother

Their innards were torn by weeping,

They had no choice

That very night

But to cry through all five watches. ${ }^{24}$

(Five Watches Tune)

In the first watch, how pained at heart, Wenrui all alone in a dilapidated kiln.

Mother in the west, son in the east, The whole day without any resources.

Oh my Heaven!

How bitter and hard the five watches are today!

In the second watch, how alarmed at heart,

Rejecting the marriage made her so angry.

My head dizzy, my eyes hazy,

I fall and get up but cannot walk.

Oh my Heaven!

This hunger in my belly is impossible to bear!

In the third watch, how sour at heart, Forced to find shelter in a dilapidated kiln.

Weeping I fall to the ground but the tears don't stop, I can only wait for dawn to leave this dilapidated kiln.

Oh my Heaven!

I entrust my life and my fate to Heaven!

In the fourth watch, how broken at heart, Suddenly in a dream I am back home again.

My white-haired old mother is seated in the hall,

Seeing my old mother I lament the injustice of it all.

Oh my Heaven!

Lacking in clothes but also without food!

In the fifth watch, how pained in feeling,

Of each ten inches of gut nine inches are empty.

My eyes are hurting and my head feels so heavy,

When I struggle to my feet I cannot move a step.

Oh my Heaven!

Just thinking of this really breaks my heart!

Now tell that when Cui Wenrui was bitterly weeping in that dilapidated kiln, he suddenly heard the crowing roosters, knew it was dawn, and left that kiln in a hurry to go

\footnotetext{
${ }^{24}$ In traditional China the night was divided in five watches of equal duration. Songs organized in five stanzas according to the five watches of the night were popular all through China.
} 
and see his old mother-but enough of that. Instead tell that Fourth Sister Zhang had been waiting for Wenrui outside the kiln, and when she now saw him come out in great haste, she promptly stepped forward and said: "Sir, I've made you suffer!" As soon as Wenrui saw her, how panicked he was, but Fourth Sister hastily addressed him again, saying: "If you accept my proposal, and you and I become a couple, I promise you that you will forever be free from disaster and enjoy every kind of luxury and status. You and I as husband and wife will take care of your mother so she will never again suffer deprivation." Wenrui replied: "Since things have come to this pass, I can do little else. But my mother is still alive, so we have to go back home and discuss this matter with her."

Once Fourth Sister heard this, her heart was secretly filled with joy, and together with Wenrui came to the old temple. After they had exchanged salutations, his mother asked him: "Whose family is this girl, and what is she doing here?" Wenrui told her what had happened to him after he had left her. His mother then asked Fourth Sister: "Where is your home and what is your name?" Indeed:

"When I tell you the situation of my family, My heart's feelings are tangled like hemp."

"My mother gave birth to four daughters; I am the youngest so I am number four.

In a year of famine we met with disaster; Fleeing from famine we came to this place.

Today I had the good fortune of meeting your son; The two of us ran into each other in the world of men. It was a good karmic bond that brought us together, So today I can become the wife of this young student." Hearing these words his mother was filled with joy: "How truly smart and intelligent a person! As my son's mother I happily agree to this marriage, But alas, our family suffers poverty and deprivation."

Hearing these words Fourth Sister was filled with joy; With a restrained smile on her face she disclosed the truth: "Dear mother, once I am your daughter-in-law, You'll never have to depend on others for clothes or food!"

From the bosom of her robe she took out four treasures And handed them to her mother-in-law to seal the match. The bed-curtains and the golden hooks were all new; Incense and wax candles were also bought. And because this day was a propitious day, They were married then and there in the old temple.

First the couple bowed to Heaven, and then to Earth;

Next they bowed to express their thanks to his mother. Husband and wife wished each other a very long life, They raised a cup of wine to celebrate the wedding. Husband and wife shared the same couch together: 
One night as husband and wife establishes a life-long bond! Heaven granted the wishes of men and made them a couple: Filled with joy and pleasure they passed the hours! $!^{25}$

Now tell that these two consummated their marriage. At dawn the next day, they once again bowed to his mother, and she was filled with joy. Fourth Sister said: "This old temple is not a place to stay forever. What was the original dwelling of your family? Why not move back there again?" Wenrui replied: "Our family used to live in Eastern Lane, but unfortunately the house was struck by lightning two years ago, and not a single tile remains. All that is left is an empty field, so how could we move there?" When Fourth Sister heard that, she produced a treasure which she handed to her husband, saying: "This is a priceless treasure. It is called a "shake-out-money tree." Shake out some silver and go buy timber and tiles and hire craftsmen to construct courtyards in front and high rooms in back so as to completely change the way you live." Hearing this, he took the shake-outmoney tree from her hands, and once he had shaken some silver from it, he went out to go and hire some craftsmen. Indeed:

Today Wenrui is going to renew his family's fortunes, So he goes out to hire the necessary craftsmen.

Now Cui Wenrui

Had silver in his hands

His heart was filled with joy,

And in great haste

He went out the gate

To hire all kinds of craftsmen.

In the eastern part of the city

He bought a number of

Serving women to serve inside;

In the western part of the city

He hired a number of

Craftsmen for every kind of job.

Within an hour

He had assembled

These craftsmen at his old house,

Where they broke the earth

Started the construction

Worked busily without a pause.

In the front compound

They raised a number

Of comfortable guest apartments;

In the rear compound

What they built were

Pavilions to look at the scenery.

\footnotetext{
${ }^{25}$ This section of verse is in seven-character lines. Indentation at the beginning of some of the lines is meant to give an idea of how the section as a whole includes subsections.
} 
They erected

A splendid gate

That was really beautiful to look at-

On both its sides

The black dragon screen walls

Were executed with consummate craft.

Through left gate-door

What had been contrived was

Golden Roosters vying in crowing;

Through the right gate-door

What had been contrived was

Phoenix Birds descending to earth.

There were wolf-teeth roofs ${ }^{26}$

And also rising $d o u^{27}$

White-washed walls

That provided an impressive sight;

And gold-coated boards

Marked the borders on both sides.

Then he bought

Fine fields and land

And he also bought

Thousands of $m u$, hundreds of qing! $!^{28}$

Sheep and buffaloes, and

His horses and mules formed herds.

Husband and wife

Set to live together till old age

In the Eastern Capital

Enjoyed their life while at home-

There was no other

As for these things

Family that possessed such wealth!

Let's put them aside

And instead take up another person, Called Half-City Wang:

He was the one

Who would be the source of trouble.

Now tell that in the Eastern Capital there lived a squire by the name of Wang Qin. His wealth was great and his character coarse; his behavior was evil and improper. If people in the Eastern Capital heard his name, they would do their best to avoid him. People called him Half-City Wang. He had been a sworn brother of Cui Wenrui's father, but when the Cui mansion had been burned by lightning so the family had been ruined and reduced to poverty, he had ignored their distress and cut off all contact with them. On

\footnotetext{
${ }^{26}$ Upturned roofs.

${ }^{27}$ The ornamented brackets between a pillar and a crossbeam.

${ }^{28} \mathrm{~A} m u$ 畧 is roughly one sixth of an acre; one hundred $m u$ make one qing 頃.
} 
the day of which we speak, he was idly walking through the streets with a boy-servant, and noticed a new mansion that was extremely impressive. So he asked his boy: "Whose mansion is this?" The boy replied: "This is the newly constructed mansion of that Cui Wenrui who is loaded with money." "So it is the mansion of the Cui family," Squire Wang said, "His father and I were friends, but he has been living in utter poverty for several years; how has he become rich again in the space of a year? Let me go over there and pay him a visit, so I can find out." As he was saying this, he arrived at the gate of the Cui mansion, and he told the gatekeeper: "Hurry up and inform your master: Half-City Wang of this city would like to see him." The gatekeeper went inside to report. Fourth Sister said: "Truly it is:

Even in a crowd there's none who cares for a poor man, But a wealthy family has relatives in distant places!'

But as he has come to pay you a visit and was a sworn brother of your father, you should go and receive him." When Wenrui heard these words, he hastily went outside to welcome his visitor. Indeed:

Wenrui went outside his gate to welcome his guest, But he had no idea what this guest had in mind.

When he was destitute, without even a grain of rice, Never had anyone come to ask after him.

When Cui Wenrui

Had heard those words

He hurried forward in great haste;

Taking large steps

He came out of the gate

And promptly asked what was up.

Outside the gate

He saw the squire

And his heart was filled with great joy;

He scurried right up

And asked the squire:

He stepped forward

"Have you been in good health?"

Grasped his hand

And led him inside.

He invited him in

Had a banquet spread

And was exceedingly diligent.

While the two of them

Were drinking their wine

And discussing this and that,

Squire Wang

Began to speak 
"Allow me to ask

Interrogating Wenrui as follows:

All this gold and silver

Where did it all come from?

Could it be that

On such and such a day

You came by some unexpected wealth?

You have oxen and sheep

And also horses and mules

In such exceedingly large numbers,

If one compared them

To all that is mine

They would top them a hundred percent!"

Now tell that Squire Wang asked Cui Wenrui: "How many fields do you have, and how many mules and horses, oxen and sheep?" Wenrui replied: "I have an unlimited store of silver, a thousand qing of fertile fields, oxen and sheep beyond counting, and three hundred serving girls." When Squire Wang heard this, he thought to himself: "People all say that I am Half-City Wang, but by the looks of it today Cui Wenrui has become the number one moneybags of them all." Cui Wenrui also said: "We don't only have fertile fields and gold and silver without number, but we also have some magical treasures that are not of this world." The squire then asked: "How about bringing them here and letting me have a look at them so I can see whether they are the real thing or fakes?" Indeed:

Face of a man but heart of a beast: that's Squire Wang;

With his devious schemes he creates all kinds of trouble.

Cui Wenrui

Went to the main hall

And grabbed those precious objects,

And explained to that

Half-City Wang

Their magical qualities in great detail:

"Our family

Has in its possession

This is an object

A splendid double-doored gate;

That in this world

Has no other like it.

One of these doors

Opens to reveal

Golden Roosters vying in crowing,

The other of these doors

Happens to show

Phoenix Birds descending to earth. 
In the courtyard in the back

Shake-out money trees

Are neatly arranged into two rows,

And the copper cash

In that courtyard

If for three days

Surges up to the mansion's back gate:

You neglect to

That shaken-out

Sweep them off the ground,

Copper cash

And then there is

Piles up more than three feet!

A treasure-collecting bowl

That gives off a clear and bright light-

Found only in heaven

But not on earth

Yet our family has one of them.

If you throw

A few copper coins

Into that treasure collecting bowl,

By the third day

Copper coins

Will fill the bowl to overflowing!"

Now tell that Half-City Wang said as soon as he heard this: "What is the point of keeping such treasures at home? Why don't you present them to the current Son of Heaven, so he will appoint you to an official post—wouldn't that be better?"

Wenrui said: "I also have seven wine cups of glass, and on them there are twentyfour beautiful maidens who hold a musical instrument in their hands and who sing and dance just like human beings." As soon as the squire heard this, he said: "Hurry up and fetch those out and let me have a look." Indeed:

It happened that these treasures did not know the stranger:

Once taken out to the front courtyard they enticed disaster.

\section{Cui Wenrui}

Seated in the high hall

Ordered one of the serving girls,

"Go and fetch the wine cups

In order for the squire

To be offered up cups of wine."

This serving girl

In a great hurry came 
To the upstairs embroidery room, ${ }^{29}$

Took the master's words

And reported them to

Fourth Sister for her to hear.

When Fourth Sister Zhang

Had heard these words,

She was upset and angry in her heart,

Saying, "As for those

Treasures of mine

They are by no means ordinary!

They are certainly not

Your run of the mill

Utensils of the mortal realm,

It took quite some effort

To borrow these things

From the depths of the Eastern Ocean!

I did it because

I wanted to save

My husband from disaster and misery,

So how can he

Take Heaven's secrets

And disclose them to mere mortals?

To take them out

And show them once or twice

Is of course not such a major matter

But I am afraid

That Half-City Wang

Will conceive all kinds of evil designs.

But if I were to

Not let him take those

Wine cups made out of glass,

I would then be afraid

Of provoking anger in

My darling dear husband."

She thought it over this way

She thought it over that way

But was unable to make up her mind.

With a hundred instructions

With a thousand biddings

She let her take them to the front hall:

"Plum Fragrance ${ }^{30}$

Take these cups

And make sure to be extra careful!

\footnotetext{
${ }^{29}$ Even women of elite families who could afford to pay for embroidery were expected to do embroidery in their private quarters.

${ }^{30}$ Plum Frangrance (Meixiang 梅香) is the generic name of a serving girl.
} 
And when he leaves the house,

To send off that Wang Qin

Squire Wang

Observe everything carefully!"

With great care

Inspected them completely.

"Truly these are

Wonderful treasures

Hard to find in all the world!"

Now tell that Cui Wenrui saw Wang Qin holding these glass wine cups in his hands, so in love with them that he could not let them leave his hands, so they used the glass cups to drink wine. When they drank, they saw the beauties on the cups start to sing and dance just like living people. This pleased Wang Qin so much that he did not know what he was doing and collapsed in laughter on the ground. He said: "Treasures of this kind could only belong to the immortals, so where did you get them from?" Wenrui replied: "Old Squire, I would not dare hide it from you. I married a woman named Fourth Sister Zhang, and she brought these treasures with her." Wang Qin then said: "If you have such a fine wife, why don't you ask her to come to the hall in front so I can pay her my respects." Indeed:

Wenrui invited his wife to greet the squire,

Not knowing it would be the cause of disaster.

Cui Wenrui,

Upon hearing

These words of Squire Wang Qin,

Said to Plum Fragrance

"Go fetch your mistress

That Plum Fragrance

I have something to tell her."

With great haste

Arrived at the inner quarters,

And said: "My lady

Master asks you

To come and greet Squire Wang."

When Fourth Sister Zhang

Had heard these words

She was upset and angry in her heart,

But if she didn't go

That would anger her husband

Something she hated to do.

Obedient to her husband

The immortal maiden from heaven

Left her room to greet a mortal man,

And as she walked 
She looked exactly

As she moved

Like Guanyin of the Southern Sea. ${ }^{31}$

She floated along-

A heavenly picture transported by clouds,

Walking along

She then arrived

Before the gate of the reception hall.

Fourth Sister Zhang

Stepping forward

Made salutation with lowered head,

Salutations finished

Right there did she

Sit down to one side.

Squire Wang

Lifted his head

And observed her in great detail:

She was indeed

Of great beauty

Just like a female immortal!

How greatly she resembled

That goddess Chang'e

Descending from the moon palace; ${ }^{32}$

Looking more carefully,

She also resembled

When that Wang Qin

$\mathrm{Xi}$ Shi arriving at the gate! $!^{33}$

Saw Fourth Sister

His heart and mind were disturbed:

It seemed as if he

Was borne by the wind

Up to the Western Heavens!

Fourth Sister Zhang

Lowered her head

And stealthily inspected him.

Looking at Wan Qin

She saw from his face

That he greatly lacked propriety:

\footnotetext{
${ }^{31}$ The Bodhisattva Guanyin 觀音 was widely venerated in female form and in this manifestation was believed to be the perfection of female beauty. One of the main centers of her cult was Mt. Putuo, a small island off the Zhejiang coast.

${ }^{32}$ Chang'e 嫦娥 is the beautiful goddess of the moon.

${ }^{33} \mathrm{Xi}$ Shi 西施 was the most beautiful maiden in the Spring and Autumn period state of Yue. The king of Yue presented her to his rival the king of $\mathrm{Wu}$, hoping that the latter would become so besotted with her that he would neglect the affairs of state. When this indeed happened, the king of Yue destroyed the state of $\mathrm{Wu}$.
} 
Hiding a roguish heart

Darting thievish eyes

He concealed a heart bent on disaster.

Fourth Sister Zhang

Having seen enough

Squire Wang

Returned to her embroidery room.

Heart harboring evil

Also went back to his own home,

Not thinking of tea

Not caring for food

In his mind he thought to himself:

"I have wives

Three or four of them

But not a one approaches her!

If Heaven vouchsafed

That that woman

Would fall into my hands,

A full bushel

Of first-rate incense

I'd burn to thank the gods!"

Thinking in his heart

Of Fourth Sister Zhang

And her startling beauty,

He conceived of a scheme

And selected with care

Some trustworthy servants.

He told the boys

"Listen to my words

Today I have

I have instructions for you.

An important matter

That Cui Wenrui

That I am going to explain to you.

Has many treasures

And also is loaded with money.

In each of these aspects

He surpasses all others

And is Number One in the Eastern Capital!

Wine cups of glass

Shake-out money trees

Who on earth ever saw such things?

Then he has

Fourth Sister Zhang

Who surpasses a heavenly maiden.

If it is the case 
That Fourth Sister Zhang

Can be brought into my house,

I promise that you will

Enjoy glory and riches

Wealth and status for the rest of your life!"

Now tell that Wang Qin upon returning home summoned his trusted servants and said to them: "Cui Wenrui not only has an enormous amount of gold and silver, but he also has that Fourth Sister Zhang, whose beauty surpasses the heavenly immortals. I've come up with a scheme. Tomorrow I will write a little note and you will go and invite Cui Wenrui, and then we'll ply him with drink till he's drunk. You will open the back gate and take gold and silver, jewelry, and pearls and precious stones, and scatter them all along the road to his house. Then we will say that I invited him for a drink out of friendliness, but that he, however, stole these precious goods from my house. We will have him arrested and taken to the office of District Magistrate Zhang. I will also take some silver with me to buy the cooperation of His Excellency, who will have him beaten till he confesses and will condemn him for robbery and theft, and throw him into jail. After that I will marry his wife as my own. How could this not succeed! This is my plan, and on no account can you reveal the truth!" Indeed:

Wang Qin devised a scheme to harm a fellow human being,

But by harming someone else he eventually harmed himself.

Squire Wang

Wrote a note of invitation

He had devised a devious scheme:

Each and every character

Each and every line

Concealed a deeply hidden intention.

Above he wrote:

"To Mr. Cui

I wish you health and comfort."

Below he wrote:

"Half-City Wang

Greets you with all due humility.

A few days ago

I bothered you

Without end,

Today I'd like

To invite you

To offer you some wine in return."

When his boy servant

Had arrived at that

Gate of the Cui mansion,

He took the note

And handed it to 


\section{Master Cui Wenrui.}

When Cui Wenrui

Saw this note

His heart was filled with joy.

When Fourth Sister

Heard about it

Her heart was filled with worry.

She stepped forward

And exhorted her husband

"Don't go to that place.

From my observation

This Squire Wang

Is not a good person at all.

I think that he

Is purposefully

I am afraid that

Plotting to harm his fellow man,

He covets our wealth

And secretly plans to harm me."

When Cui Wenrui

Heard what she said

He completely disbelieved it,

So Fourth Sister Zhang

Hastily took out some coins

And used them to divine the future.

The very first

Combination of coins

Allowed for no doubt or misunderstanding,

Spelling out: "The husband

Will be able to go

But will have no way to return."

And then the second

Combination of coins

As soon as they fell on the floor,

Spelled out: "The husband

Can go on this day,

But will meet with disaster."

But Cui Wenrui

Covering his ears,

Refused to listen to his wife's words.

He turned around

And all puffed-up

Went out through the gate of his house.

He ordered a servant

To saddle his horse

And promptly set out on his way. 
Squire Wang

Came out of his gate

And welcomed him with great honor.

He brought him inside

And laid out a banquet

Making a show of all due respect.

The squire said:

"My dear Mr. Cui

A cup of wine will aid our merriment.

Although lacking fine wine

And lacking good dishes

Please don't think it beneath you-

Please don't refuse

Please don't put me off

But instead enjoy a few cups of wine!"

Here a cup

There a cup

Cup after cup he urged him on;

Offering up one toast

And then yet another

Toast after toast he offered.

When Cui Wenrui

Had drunk until

He was drunk as drunk could be,

Squire Wang

Ordered his servants

To tie him up as tight as could be.

He loudly cursed him:

"You Cui Wenrui!

You have stolen my gold and silver!"

He cursed Wenrui

In such a way that he

Although having a mouth could not utter a word.

"I invited you

To come and have some wine

Out of the pure goodness of my heart:

Who would have thought

That you on the contrary

Within a short time

Would steal my gold and silver?"

They had taken Wenrui

And forcibly shackled him tight,

And packed him off

To the magistrate's office

So that the case could be tried. 
Now tell that once Wang Qin had arrested Wenrui, he took him to District Magistrate Zhang $\mathrm{Du}$, and there lodged an accusation against him. Once Zhang Du had read this statement, he promptly took his seat as judge, and the various court attendants brought out Cui Wenrui. His Excellency the District Magistrate asked him: "That Squire Wang invited you to drink some wine out of friendliness, but harboring evil intentions you stole his silver, and you also kidnapped his wife! Confess to your crimes according to the truth!" When Wenrui heard this, he kowtowed and said: "I have no idea how to rob people, and on top of that I am extremely wealthy, so why would I rob him? He claims that I kidnapped his wife, but Fourth Sister has been my wife for three years, so why has he waited until today to lodge an accusation? It is obvious that he hopes to obtain my possessions by harming me, and that he hopes to use force in order to make my wife his own. May Your Excellency examine this clearly!"

District Magistrate Zhang sent away Cui Wenrui and then asked Wang Qin: "The two of you are both loaded with money, so why would he want to steal your gold and silver? This must obviously be a false accusation!" When Wang Qin noticed that the case was not going his way, he hastily produced three hundred ounces of first-rate silver, which he presented to District Magistrate Zhang. When the latter saw that amount of money, his desire was aroused, and he told the court attendants to bring Wenrui back into court for further interrogation and further questioning. Indeed:

Pure white silver can buy people whose hearts are black, So that during interrogation blatant lies become the truth.

Magistrate Zhang

As he held court

Manifested a towering anger and rage,

And ordered his underlings:

"Hurry up and have

That criminal brought before the bench!"

Then he shouted: "Wenrui

Confess to every item

In accordance with the facts of the case,

And you'll be spared

On this very day

When Cui Wenrui

Being beaten till the blood flows!"

Heard these words

He was filled with fear and trepidation,

And he cried out:

"Your Excellency

Please listen carefully to my explanation!

Your Excellency

I would not dare

Blindly confess to this accusation.

Only after receiving an invitation

Did I go down to 
Right in the midst

Pay a visit to his house,

Of drinking some wine

His servants started to holler and scream;

They took hold of me

And against all reason claimed

That I had stolen his gold and silver."

When Magistrate Zhang

Had heard this statement

His heart was filled with a towering rage,

He shouted an order:

"Now throw him down

And apply the five instruments of torture."

No sooner had they started

When they had already administered

Fifty strokes of the broad board,

And then they gave him

Forty strokes of the cudgel

That Cui Wenrui

Till his skin was broken and his flesh was torn.

Suffered these tortures

But was completely unwilling to confess,

So His Excellency said:

"Into his body

Nail some iron nails!"

The various yamen attendants

Hearing this order

Did not dare to tarry or delay,

So they picked up

Some iron nails

And in the courtyard hammered them in.

Then they threw Wenrui

Down on the ground

And doused his body with boiling water,

From the eastern side

To the western side

Without showing any compassion at all.

The skin and flesh

On his whole body

Was completely scalded and softened,

So that he closely resembled

A fish that had been stripped

Of all layers of its scales and skin.

The attendants were ordered

To go and bring out

Iron chains heated red-hot, 
And wrap them around him

In order to see

Whether he would confess or not.

Cui Wenrui

In a flash

Could not bear the torture anymore,

And against his will

Saying whatever came into his head

Confessed in conformity with the accusation:

"This Squire Wang,

It was his gold and silver

That I went and stole.

I crawled over his wall

And dug under his gate

In order to steal his gold and silver.

I took his wife,

I stole his riches

The words above

Transgressing the royal law of the land-

Are a true statement indeed

I wouldn't dare hide anything."

Magistrate Zhang

Seeing that he had confessed

He had him shackled

Had him sign the confession and affix a thumbprint,

And then escorted to

That dark and dreary jail!

When the district magistrate

Had been informed of this

He did not dare waste a moment;

When Squire Wang

Had received this news

A happy smile covered his face,

And leading a bunch

Of uniformed troops

He set out to welcome the bride.

One of the pages

Informed Fourth Sister

As fast as he could of this news.

The troops told her:

"Your husband

Stole away from

While drinking wine at the Wangs,

Squire Wang

Quite a lot of gold and silver.

Magistrate Zhang 
Has condemned him to death

And has him locked up in the jail,

And His Excellency

Has in his verdict

Awarded you to Squire Wang.

It has been given to us

To carry you over to

His mansion for the wedding,

When you enjoy luxury and glory

And experience wealth and status

Never forget our services to you!"

When Fourth Sister Zhang

Had heard these words

She was filled with a towering rage,

She cursed that dog of an official

And longing for her husband

Myriads of arrows pierced her heart.

She blamed her husband:

"At the time you

Did not listen to my advice,

Now you've been unjustly jailed

Suffered every kind of torture

Who is it that is to blame?"

The troops and cavalry

Urged Fourth Sister

To set out with all haste,

But Fourth Sister Zhang

Lowering her head

Came up with a scheme of her own.

Now tell that when Fourth Sister heard the soldiers say that her husband had been thrown in jail, her heart was filled with rage. While the troops were urging her to get going, she employed her supernatural powers and dispersed them in all directions. The troops informed the district magistrate. When Magistrate Zhang heard this, he was greatly astonished, and this time he dispatched three hundred troops to go and arrest Fourth Sister. The troops surged forward like a swarm of bees and all together came into action with a great show of power, but Fourth Sister recited her true spells and magical words, and when she pointed a finger to the sky, a raven-wood cudgel came rolling down and delivered such a beating to these troops that some lost their lives and some were wounded, leaving only a few to run away and report the news.

Fourth Sister Zhang

Displayed her supernatural powers

With their myriads of transformations,

And she killed

Of those troops 
More than two hundred men,

With one blow of the cudgel

She gave them such a beating

They fled in all directions;

With one blow of her staff

She gave them such a beating

They were reduced to utter disorder.

Magistrate Zhang

Received such a beating

That he knew he was in a bad situation,

So he ordered his subordinates

To call up and mobilize

The whole army to join the campaign.

Five thousand men

Surrounded the Cui mansion

Layer after layer deep,

But Fourth Sister Zhang

At such a sight

Only smiled a cold smile.

She said "District Magistrate

Hurry up and call back your troops

And return my dear husband to me-

That will save

You and me

From having to take up arms and fight.

But if you will not

Call back your troops

And continue to besiege the Cui mansion,

When the time comes

I will force you to

Lose your life and go to the land of darkness."

Magistrate Zhang

Called out to his underlings:

"Capture and arrest that demonic monster!

She has killed

Government troops

Her crime is not light!

Her husband

That thief

How can there be

Has been thrown in jail,

This sort of

Brazen demonic monster?"

When Fourth Sister Zhang

Had heard these words,

Her heart was filled with anger and rage, 
Below her feet

Auspicious clouds rose up

And she stood in the middle of the sky.

Then she changed

Into seven dragons

Rising higher and higher in the clouds,

And threw one needle

For embroidering flowers

Up into the emptiness of the sky.

She called up a twister,

Sent down heavy rains

Thunder and lightning booming together!

The heavens turned black

And the earth was darkened

Scaring everyone out of their wits.

When she had captured

Magistrate Zhang

She wanted to immediately kill him,

But then she feared

That the Jade Emperor

Would punish her for that infraction.

So she took that scoundrel

And strung him up by his hands

On top of the tower above the city gate,

And gave him such a beating

That from his whole body

Blood came dripping down.

She also gave him

So many strokes with a cudgel

That his skin broke and his flesh was torn,

And Magistrate Zhang

Under such heavy torture

He cried out:

Sank into a stupor.

"Young lady

Please spare my worthless life!"

He also cried out:

"Your ladyship

If you let me live what life is left to me,

From this day forward

I will never again dare

Act in such an outrageous way!"

When she saw Zhang Du

And how he implored her

In such a miserable manner,

Fourth Sister Zhang 
Upon hearing these words

Lowered her head and pondered the matter:

In her heart

Compassion arose

And she ended up sparing his life.

Now tell that once Fourth Sister had released Zhang Du, she returned home and told Wenrui's elderly mother: "You son is languishing in jail, but just put your mind at rest and stay home and watch over things. I am going to go save my husband, and when that's done we can take further measures." Having said that, she went through the gate and took off, and before too long had arrived at Zhang Du's yamen. When Zhang Du saw Fourth Sister, he was so scared that his soul flew off beyond heaven, and he ran for his life! Indeed:

Fourth Sister had freed Zhang Du, And now Zhang Du ran for his life.

Fourth Sister Zhang

Having arrived

At the office of the district magistrate,

Promptly scared that

Magistrate Zhang

So that he hurriedly ran for his life!

Following her nose

She found herself at

The southern jail,

She saw inside

That southern jail

Quite a number of convicts.

Each and every one

Suffered bitter pain

Their hair unbound and hanging loose.

"But I don't see

My own dear dear husband-

Not a shadow of him to be found!"

Then when she opened

The door of the eastern jail

And took a look inside,

What she saw was

A face and appearance

That was black and dirty!

Only when Fourth Sister

Had gone up to him

And observed the face closely,

Did she recognize

Her very own 
With both arms

Darling husband!

She caught up in an embrace

That husband of hers,

And from her eyes

Tears gushed forth

And she let out a cry of woe.

She cried out:

"My dear husband

You suffered a terrible wrong,

But this was because

Of your own mistake

So whom can you blame?

Think back to that time

When I exhorted you

But you refused to listen!

But now that you

Have suffered all kinds of torture

As she was speaking

How could I bear to not do anything?"

She displayed her powers

And spat out some immortal water,

That took her husband's

Iron shackles and cangue

And made them fall into the dust.

Cui Wenrui

Saw that Fourth Sister's

Magic powers were very great,

In that prison

All the other convicts

Asked him to ask for her help!

Now tell that when Fourth Sister Zhang saved her husband in the prison, all the criminals saw it very clearly. They all knelt down on the floor and implored her: "Your ladyship, please also save us from this prison! We will never forget such a great favor!" When Fourth Sister heard these words, she recited her magic words and true spells, and promptly the iron shackles and cangues on those criminals fell to the floor. They hurried to express their gratitude to Fourth Sister, and then each went back to his home.

Employing the true fire of samadhi Fourth Sister burned down the prison. Once they were back home, husband and wife discussed how to kill Wang Qin and his whole family. Indeed:

The golden lad and jade maiden met once again:

Where clouds part bright daylight can be seen!

Once Fourth Sister Zhang 
Had saved her husband

They returned to their mansion;

They greeted his mother

And then discussed

How they could greatly take revenge.

As they were talking

They watched the sun

Sink down behind the western hills,

And they pondered

How they would the next day

Again confront their arch-enemy.

The two of them

Could not for one moment

Let go or part from each other,

But suddenly they heard

From the drum tower

At the first watch

The beating out of the watch. ${ }^{34}$

They entered the embroidery room

Silver lamps gleamed on high;

At the second watch

Husband and wife

Were in perfect emotional union;

At the third watch

Underneath a red damask quilt

The two of them went to bed;

At the fourth watch

They were holding hands

Hard to part or divide.

At the fifth watch,

The Golden Rooster crowed

And the sky became very bright.

They hastily got up

And went to the Wang mansion

Where she greatly displayed her powers.

With one shake of her body

She was transformed

To a height of thirty-six zhang, ${ }^{35}$

First she grabbed that

Harmer of men

That villain Wang Qin.

"You sought to ruin me

And also to harm

My darling husband,

\footnotetext{
${ }^{34}$ The text actually says that the third watch was beaten, but that makes no sense.

${ }^{35}$ One zhang 丈 equals ten Chinese feet (each foot was slightly shorter than an English foot).
} 
I will cause you

This very day

To meet the king of the dead.

I will capture your

Entire household

And completely slaughter them all,

I will snatch you up

You villain Wang Qin

And mince your corpse into a myriad pieces!"

She tore open his belly

Gouged out his eyes

And chopped his whole body into mincemeat.

As for the furniture

And the utensils

She smashed them all to bits and pieces.

Fourth Sister Zhang

Greatly took revenge

But no more of that for now,

Instead let us speak

Of Magistrate Zhang

Who reported the case to Judge Bao:

"In the Eastern Capital

On Old North Street

There is a small lane;

In the mansion

Of Cui Wenrui

A demonic monster has appeared.

Its name is called

Fourth Sister Zhang

And she has great supernatural powers;

She and that

Cui Wenrui

Cohabit as husband and wife.

Squire Wang

Invited Wenrui

With the best of intentions indeed-

How could he know

That this Wenrui

Would steal his silver and gold?

Squire Wang

Brought that criminal Cui

Down to my yamen;

With due haste I

Accepted his complaint

And read it very carefully.

I ordered my troops 
To go to his house

To conduct a thorough investigation,

But she struck dead

My soldiers,

Two hundred men and more!

She also released

From my prison

Three hundred criminals,

With fire

She further burned down

That jailhouse of mine.

To get revenge

She went to Wang's house

And wiped out the entire household,

I implore Your Honor

To hurriedly apprehend

That demonic monster!"

Now tell that Judge Bao, upon hearing this, thought to himself: "How is it possible that such a demonic monster manifests itself in the present world of peace and order? This Zhang Du is ordinarily not upright in the way he conducts official business. I have always wanted to remove him but I never had an opportunity. Now that he has come to report to me today, I won't be able to stop worrying about him." But let's put Zhang Du aside for the moment - he will be dealt with properly later. Let's only tell how Judge Bao ordered Wang Zhao and Ma Han to ready their horses and men. Taking his demonoscope ${ }^{36}$ with him, he set out with his party to go see. Indeed:

Possessing demon-beheading sword and demon-revealing mirror, During the day he judges the living and at night he judges the dead.

That Judge Bao

Having heard this report

Pondered the matter in his mind;

He ordered Wang Zhao

And also Ma Han

To hurriedly go before.

They carried the bronze chopper ${ }^{37}$

And also the iron sword-

They also took

How bright they gleamed!

The demonoscope

To capture that demonic monster

And the peach wood shackles

\footnotetext{
${ }^{36}$ Zhaoyao jing 照妖鏡: a mirror that reveals the true shape and appearance of shape-shifting demons.

${ }^{37}$ The Judge Bao of the Qing dynasty had three of these huge choppers ( $z h a$ 鈴) that he used for executing different classes of people.
} 
And willow wood cudgels

Feared by gods and ghosts alike.

Those carrying the sword

And those carrying the chopper

The bronze "melons" 38

Followed closely behind.

And crescent moon hatchets

Covered sky and earth,

While the gods of the hills

And the gods of the soil

Accompanied him with due diligence.

Within a short while

They had arrived

Outside the gate of the Cui mansion,

And Lord Bao called out:

"Quickly capture and arrest

That demonic monster Fourth Sister!"

This so scared that

Household of people

That their gall bladders ${ }^{39}$ shook and their hearts were frightened,

But Fourth Sister Zhang

On hearing this command

Only smiled a cold smile.

She went outside

And lifted her head

And took it all in:

On all four sides

They were surrounded so tightly

That not a drop of water could leak out!

Fourth Sister Zhang

Exhorted Judge Bao:

"Hurry up and pull back your troops,

Otherwise with eyes wide open

And quite intentionally

But when Judge Bao ${ }^{40}$

You will be offering yourself up to disaster!"

Saw Fourth Sister

He called out: "You demonic monster,

I ordered my subordinates

To hurriedly apprehend you

So do not do anything foolish."

The Star of Literature

\footnotetext{
${ }^{38}$ Heavy metal balls mounted on top of a short staff and used as weapons.

${ }^{39}$ The gall bladder was considered the locus of courage in the body.

${ }^{40}$ The text actually refers to him here by a title given him in popular literature, Wenzheng 文正 (“Cultured and Upright").
} 
Served as prime minister ${ }^{41}$

But failed to recognize her as an immortal,

Because he believed

The report of Zhang Du

He wanted to take military action!

Now tell that Judge Bao told his underlings to bring out the demonoscope. Fourth Sister said: "Star of Literature, if you can display my true nature in that demonoscope, I will truly be impressed by your abilities!" Judge Bao employed his demonoscope and shone it again and again on her, but he did not see any demonic shape at all! Indeed:

He shone the magic mirror again and again,

But no demonic monster appeared therein.

When her left side

Came before the mirror

No form or reflection appeared;

When her right side

Came before the mirror

No human shape could be seen either.

Chancellor Bao

At this time

Saw rage rise up in his heart,

He ordered his underlings

To advance together

And apprehend that woman.

There was Wang Zhao

And also Ma Han

Who advanced and began to fight,

But Fourth Sister Zhang

Suppressed her anger

And only played a little trick on them.

First she employed

An eye-blinding magic

So their eyes were blinded by flowers;

Next she employed

A body-fixing magic

So their bodies were fully immobilized.

That Wang Zhao

Could not lift

His awe-inspiring running feet,

And that Ma Han

Could not display

The martial arts of all his limbs.

\footnotetext{
${ }^{41}$ In popular literature Judge Bao was thought to have been an incarnation of the Star of Literature (Wenqu xing 文曲星). In real life he never served as prime minister.
} 
She took Judge Bao

And also blinded him

So that his eyes blurred and pupils went dark;

She pulled him down from his horse

And he was fixed and immobilized

By the main gate of the front courtyard.

This body-fixing magic

Had immobilized

The five hundred government troops,

Scaring those

Various official troops

So that their gall bladders quaked and their hearts were frightened.

One of those present

Hastily made a bow

For he had a quick mind and keen eyes,

He said: "Milady,

As your powers are divine,

Please do us a favor!

That actually is

The court-appointed

His Honor the Chancellor,

If you kill him

You are bound to arouse

The towering rage of the imperial court!"

Fourth Sister Zhang

Was not in the least afraid

Of either the imperial court or beyond,

This so scared

Cui Wenrui,

That he hurriedly pled on Bao's behalf.

So Fourth Sister

Listened to her husband,

And released Judge Bao,

But Judge Bao

Memorialized the Humane Ancestor

Informing him in great detail of the events.

Now tell that when Judge Bao had entered the palace and paid his respects to His Majesty the Humane Ancestor, he told how a demonic monster had appeared in the mansion of Cui Wenrui of the Eastern Capital: her name was Fourth Sister Zhang; she was sixteen years of age, possessed great supernatural powers, and was capable of many transformations. She had murdered all the members, old and young, of the household of Wang Qin, and had killed a complete detachment of men and horses under Magistrate Zhang. "When I went forward to capture and arrest her I returned greatly defeated. I was also unable to use my demonoscope to find out what kind of demonic monster she was. I 
therefore request Your Majesty to dispatch a major force to go capture and arrest her." Indeed:

Judge Bao entered the palace and bowed to the Humane Ancestor:

"The divine power of Fourth Sister even frightens the lofty skies."

Judge Bao declared:

"There are no other people

Who can capture this demonic monster:

All you can do

Is to summon the Yangs and the Huyans

And have both clans lead forth their troops."

The Humane Ancestor

Hearing this report

Promptly proclaimed an imperial edict,

An emissary

Went first to that

Mansion of Heavenly Waves. ${ }^{42}$

He first paid his respects

To Taijun the Matriarch, And presented the imperial order,

And the Matriarch,

Having received the edict

Hurriedly read it through:

"In the Eastern Capital

A demonic monster has appeared

Harming our troops and killing our officers,

So your great-grandson

Yang Wenguang

Is ordered to mobilize his entire army!"

Yet another emissary

Also had arrived

At the mansion of the Huyan family,

Where Huyan Qing

And the princess

Came forward to receive the edict.

As His Imperial Majesty

Had proclaimed this edict

They didn't dare tarry or delay,

But with all due speed

Proceeded to the parade-ground

And mobilized their troops for action.

Yang Wenguang

And Huyan Qing

These two great generals,

${ }^{42}$ Home of the Yang family. 
In accordance with the edict

Departed the palace gates

In order to apprehend that monster.

Leading cavalry and infantry

They ordered their whole army

To raise a battle cry all in one voice,

As three cannons resounded,

They arrived outside

The gate of the Cui mansion.

On all four sides

They tightly surrounded

This great mansion of the Cui family,

When commanded three times

They shouted in one voice:

When Cui Wenrui

"Apprehend that demonic monster!"

Saw how things were,

He was scared completely out of his wits,

Trembling with fear

He said: "My dear wife

This disaster we've called down is not light!"

But Fourth Sister

Was not concerned in the least

In her eyes they counted for nothing at all.

She was not afraid

Of these great generals

"Just watch how I

And their millions of strong troops:

Make my advance

See if those men and horses,

Each and every one

Are not caused by me

To go and meet the king of the dead!"

When she rushed outside

She came face to face

With General Huyan Qing, ${ }^{43}$

He cursed her:

"How dare you

Demonic monster Fourth Sister!

Hurry over

And give up your life

Better not act foolishly,

That would avoid

Our having to use our troops

Bringing destruction and loss of life."

${ }^{43}$ The text here gives $\mathrm{Hu}$ as his surname and Yanqing as his personal name. 


\section{When Fourth Sister Zhang}

Had heard these words

She did not react by word or expression,

But recited true spells

And recited magic words

She also took out

That penetrated the very gate of heaven!

A golden hairpin

On which she blew one puff of breath,

Whereupon it turned

Into a yellow dragon stallion

That surpassed any horned dragon at leaping;

She also took hold

Of a silk handkerchief

Which she twisted a few times.

It changed into a golden tiger

And into a jade unicorn

Both displaying blinding light.

A golden cup

She took in her hands

And turned it round several times,

One puff of breath

And it changed into

A black-bladed sword!

Huyan Qing

Observing how Fourth Sister

Could transform with a shake of her body,

Raised his sword

Rushed forward to fight

On the other side

His heart frightened and gall quaking!

Yang Wenguang

Felt a towering rage in his heart,

He rushed forward

To lend a hand

And the ether of death rose up in thick clouds!

Spear crossed blade

And blade crossed spear

Crashing together with deafening noise,

They fought in such a way

That throughout the Eastern Capital

Earth and sky were filled with darkness.

Fourth Sister Zhang

Fighting these two generals

Did not dare treat them lightly,

So she jumped out of the fray 
And rose upon a fine cloud

To stand in the empty sky.

Toward the Gate of Heaven

She pointed just once,

And the entire sky turned black:

There was swirling dust

And flying stones

That threw the army into disorder!

They rained down so thickly

That Huyan Qing

Could not distinguish north from south;

They rained down so thickly

That Yang Wenguang

Could not separate east from west.

\section{Fourth Sister Zhang}

Then produced

The soul-catching bottle:

With a wave of her hand

Generals Yang and Huyan

Were both sucked into this magic bottle.

Using flying stones

She caused the death

Of a thousand officers and troops,

All of the army

Seeing this state of affairs

Decided it best to run for their lives.

Now tell that when various officers and troops reported their defeat to the Throne, this frightened His Majesty the Humane Ancestor so much that he was at a loss for what to do. He hurriedly dispatched Judge Bao to go to the Mansion of Heavenly Waves to again raise troops to come to the rescue. When the Matriarch heard his report, tears flowed from her eyes, and she said: "I don't know how many men of the Yang family have died for the sake of the Song empire! Let me go and capture this demonic monster and free the dynasty from this harm." When Judge Bao heard this, his heart was filled with joy, and he said: "If the women generals of the Yang family join the battle to capture this demon, success is ensured. I will, for the moment, go back to my office in the southern city." ${ }^{, 44}$ Indeed:

When he heard these words, Lord Bao was filled with joy:

The women generals of the Yang family would join the fray.

\section{When Lord Bao}

Saw that the Yang family

\footnotetext{
${ }^{44}$ The office in the southern city is the yamen of the prefect of Kaifeng. The historical Bao Zheng only served as prefect of Kaifeng for a little more than one year, but in the popular mind Judge Bao was identified with that function.
} 
Had women generals who were so heroic,

He knew that when they went

To apprehend that demonic monster

They were certainly bound to succeed.

But let's not talk

About Black-Faced Judge Bao

Who returned to his own office,

But let's only talk

Of those heroic

Yang family women generals.

\section{Third Sister Li}

Went together with them

To go take great revenge,

There was also her daughter

'Prettier than a Flower'

Who wanted to make a contribution too.

Mu Guiying

Called the roll

She next arrived

And then left the Yang family mansion;

At the Huyan family mansion

Where she fully explained the situation.

At the Huyan mansion

Out there came

When she saw

The princess [Lanfeng].

Mu Guiying,

She asked about all the details.

'Prettier than a Flower'

And Third Sister Li

Completely told them to her.

On this side

This stirred to rage

"My husband

The princess Lanfeng.

Huyan Qing

Has suffered such a terrible disaster,

I too today

Definitely want to

Capture and arrest that demonic monster!"

These two families

Mobilized their troops

And set out to pay a visit to His Majesty,

Receiving his order

To lead their troops 
These two families

They were sure to achieve immediate victory.

Consisted exclusively

Of female troops and female officers;

They broke up camp

And soon arrived

In the golden hall

At the richly decorated palace gate.

They kowtowed to the emperor

Thanking His Majesty for his grace;

As soon as he saw them

The Humane Ancestor

And he declared:

Was filled with great joy in his heart,

"Mu Guiying

Will be commander-in-chief.

My daughter Lanfeng,

Do not be lax:

I appoint you as vanguard."

Now tell that when Princess Lanfeng had been made the captain of the vanguard, she selected three thousand mounted soldiers, and after she had fired a cannon, they all set out. The troops shouted their battle cries and the war horses snorted and neighed. Within a short while they had arrived outside the gate of the Cui mansion. They surrounded it tightly, and shouted: "You demonic monster, hurry up and come out here to do battle!" Cui Wenrui was so scared that he did not know where to hide himself, and when he tried to escape through the back door, he was arrested by women generals of the Yang family. At precisely that time Fourth Sister Zhang was sitting in her embroidery room and heard the shouting and noise of men and horses. A serving girl came to report, and only then did she realize that the female generals of the Huyan and Yang families had surrounded the mansion. Fourth Sister went outside to have a look. Indeed:

She greatly created havoc in the Eastern Capital, Time and time again pitched battles were fought.

Mu Guiying

Ordered her troops

To pitch camp and build fortifications,

And she encircled

The Cui mansion

So tightly no drop of water could escape.

This angered

Fourth Sister Zhang

Her heart was filled by a towering rage;

She swiftly came outside

Mounted her horse 
And opened an armed attack.

'Prettier than a Flower'

Came forward

To meet her in battle,

These two women,

Compared their prowess

Each displaying her supernatural skills.

They fought and fought

Some tens of rounds

Without deciding winner and loser,

Then 'Prettier than a Flower'

Spat out some magic water

And rose up into the empty sky;

Holding in her hand

A demon-subduing cudgel

She shook herself to transform,

And transformed herself

Into a three-headed

Six-armed giant:

When she opened her mouth

It was as big as a blood bowl

With teeth like awls of steel,

Her two eyes

Resembled bronze bells

As if about to devour human beings!

When Fourth Sister Zhang

Saw this apparition,

A faint smile briefly crossed her face,

She pulled out

Her embroidery needles

And threw them high into the sky.

Reciting a spell

She turned them into

Who rose up into

Ten fierce tigers,

The middle of the sky

Ready to manifest their great might.

Shaking their heads

And sweeping their tails

They bared their fangs and claws,

They wanted to eat

That three-headed

Six-armed giant.

'Prettier than a Flower'

No sooner saw them

Than she turned around and took to her heels; 
On the other side

Third Sister Li

Flourished her blade of steel.

She recited true spells

And magic words too

And a wild storm started to blow;

She made sand swirl

And stones fly

It was like thunder booming.

But Fourth Sister Zhang

Put into employ

A turn-around magic,

And that swirling sand

And flying stones

Turned around to batter 'Prettier than a Flower'!'

Mu Guiying

Seeing this

Was filled with a towering rage,

And she threw paper men

And also paper horses

But Fourth Sister Zhang

Up into the sky.

Spat out magic water

And darkened heaven and earth:

A dust storm blew

Torrential rain fell

Thunder crashed and lightning flashed!

But from the Huyan mansion

There now rushed forward

Young Princess Lanfeng,

Her forces

And those of the Yangs

Collaborated in a coordinated attack.

\section{Princess Lanfeng}

Made use of sesame seeds

Onto those seeds

Three pecks and three cups in all,

She blew a breath

And transformed them into an army.

All of these troops

Raised blades of steel

And rushed forward to join battle;

In a great hubbub

They surrounded Fourth Sister

So that she was unable to make any move.

${ }^{45}$ As 'Prettier than a Flower' has already fled the battle field, this is probably a mistake for Third Sister Li. 


\section{But Fourth Sister Zhang}

Was not afraid at all

At the loud shouts of the enemy troops;

She gave her body a shake:

Ten turned to a hundred

A hundred to ten million!

They dashed to the east

They fought to the west

And surrounded the government soldiers.

'Prettier than a Flower'

And Princess Lanfeng

Sought to block them in the west and in the east.

Third Sister Li

Was so anxious that

She could not make a move,

But Guiying cried:

"Six-Armed One

Don't forget to come to our rescue!"

In this battle

They fought until

The sky had lost its light:

Wild winds blew

Torrential rain fell

Sun and moon lost their brilliance.

The various women generals

Were lost in a haze

Dashing to the east and the west;

Fourth Sister Zhang

Took out her magic bottle

And captured the souls of them all.

Within a short while

She had captured

All the Huyan and Yang women generals,

And before anyone knew

Evening had fallen

And the moon had risen above the buildings.

But when she went home

No husband was there

Cui Wenrui

And tears flowed forth from her eyes,

Had been captured

And was enduring suffering.

Fourth Sister Zhang

In her embroidery room

Pondered this matter all by herself:

"I still will have 
To go out again

To save my darling and bring him home!"

Now tell that while Fourth Sister Zhang was in her embroidery room she thought about her husband who was still locked up in custody. Disregarding her fatigue from doing battle, she wanted to immediately go and rescue him. Her husband Cui Wenrui had been captured by the women generals of the Yang family and taken to the yamen in the southern city. Fourth Sister Zhang hurried there, and using a body-concealing magic, saved him and brought him home.

Let's tell instead that Judge Bao thought to himself: "This Fourth Sister Zhang is not some demonic monster. She must be an astral deity who has escaped from somewhere or other, but she is creating such havoc in the Eastern Capital that no one can live in peace. As for the generals of the Huyan and Yang families, I don't know if they are alive or dead. The only solution is for me to go and conduct an investigation in the offices of the underworld and in the palaces of heaven." When he had reached this conclusion, he promptly ascended the palace hall and memorialized the Humane Ancestor. When the latter had heard his proposal, he gave him a golden seal, and told him to go and come back as quickly as possible. Indeed:

When the Humane Ancestor heard Judge Bao's proposal, He promptly offered him three beakers of imperial wine. In order to apprehend and arrest that Fourth Sister Zhang, Judge Bao has to travel through underworlds and heavens.

That Judge Bao

Drank the imperial wine

And thanked the Humane Ancestor;

He then took out

The Yin and Yang boards ${ }^{46}$

Judge Bao's

And the headrest that calls back the soul.

Three ethereal souls

Arrived in the Dark Offices,

His seven earthly souls

Also found their way

To the middle of the underworld.

Before long

He had arrived

At the precious hall of King Yama,

And the ten infernal kings

Together came outside

To receive Judge Bao.

They all asked him:

"Star of Literature

What business brings you here?"

\footnotetext{
${ }^{46}$ When sleeping on a bed made of these boards, Judge Bao's souls can travel through heavens and hells.
} 
Judge Bao replied:

"I have come here

To investigate the case of a demon.

In the Eastern Capital

There has appeared

A horrific demonic monster,

And I very much fear

That she will bring to disorder

The empire of the Song dynasty.

The finest heroes

Went to arrest her

But they all failed to achieve victory,

Causing the Eastern Capital

To be so disturbed

That everything is out of joint.

In your halls

Has there gone missing

Any ghost or deity perhaps?

With great care

Please make a check

To see if all is as it should be."

Now tell that when the ten kings of the infernal courts had heard the request of Judge Bao, they ordered the infernal judges to go and investigate each bureau of the underworld administration to see which bureau might have lost track of a ghost or deity. When the infernal judges received this command, they completely investigated all eighteen layers of hell, but none had lost track of a ghost or deity. When Judge Bao heard this, he took his leave of the infernal kings.

He then went on to the Thunderclap Monastery in the Western Heaven, where he met with Our Buddha the Tathagatha. After he had paid his respects, he once again told how a demon had appeared in the Eastern Capital and asked Lord Buddha to conduct an investigation. The Tathagatha dispatched people to completely check on the Eighteen Arhats, the Eight Great Diamond Kings, and the Thirty-Six Devas, but they were all at their posts and none had run off. Judge Bao quickly took his leave of Lord Buddha and at the third quarter of the first hour he arrived at the Southern Gate of Heaven to conduct an investigation in the palaces of heaven. Indeed: ${ }^{47}$

Judge Bao lay down

On his Yin and Yang couch

Wanting to go up to the palace of heaven,

And before too long

He did arrive

At the Southern Gate of Heaven.

\footnotetext{
${ }^{47}$ In this text prose passages as a rule are followed by a couplet or a quatrain introduced by this phrase “Indeed" (Zhengshi 正是), but no couplet or quatrain appears in the original text at this point.
} 
The Star of Great White ${ }^{48}$

Escorted Judge Bao

To go see the Jade Emperor,

And Jade Emperor Zhang

Hurriedly began to speak

Asking the chancellor:

"I dispatched you

Star of Literature

To go down from this heavenly palace,

Together with the Song court's

Humane Ancestor

To rule the country and pacify the people.

For what reason

Have you now come to

The Precious Hall of the Divine Welkin?

Could it be that

The Humane Ancestor

By any chance has treated you unfairly?"

When Chancellor Bao

Heard these questions

He hurriedly stepped forward and replied:

"Your Imperial Majesty

In the Eastern Capital

A demonic monster has appeared.

She has brought down

Quite a number of

Loyal and excellent top generals,

She has also killed

Countless numbers of

Ordinary people and commoners!

I have been wondering

Whether up here in heaven

Some astral deity might have escaped,

And created such havoc

In the Eastern Capital

That the people there cannot live in peace?

So I implore Your Majesty

To very carefully

Do a complete investigation,

To see which deity

May have escaped

So she may be captured and returned to heaven."

Now tell that the Jade Emperor, when he had heard this report, ordered the divinities on duty for that day to check the Twenty Eight Asterisms, the Nine Astral

${ }^{48}$ The Star of Great White is the planet Venus, one of the "moving stars." 
Palaces of the Dipper, the Five Lakes and the Four Seas, and the Twenty Four Grottoes, but they all reported that no deity had escaped. The Jade Emperor then gave an order for the investigation of the Dipper and Buffalo Palace of the Queen-Mother. Indeed:

Ascending to heaven, entering the earth: he searched everywhere, But still he did not know where Fourth Sister had come from.

That Queen-Mother

On receiving this command

Was in no position to ignore it,

In Dipper and Buffalo Palace

She very carefully

Investigated so that all was clear.

From the start

Down to the end

They searched here and searched there:

In Dipper and Buffalo Palace

Only one person was missing:

The Jade Emperor's own fourth daughter!

From the celestial palace

She had been gone

The space of three days,

But in the realm of men

That was equal to

That Judge Bao

Three years and more!

Hearing this report

Was completely scared out of his wits:

So all along it had been

The Jade Emperor's

Fourth daughter no less!

The Jade Emperor said:

"Star of Literature

First go back to earth,

In the Eastern Capital

Inform the Humane Ancestor

That I will dispatch my celestial troops.

First I will dispatch

From the Dragon King's Palace

Water Dragon Crown Prince;

Second I will dispatch

Li Nezha

To restore order to heaven and earth."

That Judge Bao

Thanked the Jade Emperor

And quickly left the palaces of heaven; 
On the soul-recalling headrest

He woke from his sleep

And so returned to this realm of light.

In the five watches of the night

He had completely traveled through

Both the underworld and the heavens,

And with great pleasure

Reported to the Humane Ancestor

The success he achieved on this mission.

The Humane Ancestor

Poured him imperial wine

And hurriedly expressed his thanks to Judge Bao:

"You have investigated

The heavenly palaces

So what was the cause?"

Chancellor Bao

Memorialized the emperor

As your minister I

"Please listen to my clear report,

First went to

The offices of the infernal bureaucracy,

Arriving there

A complete investigation was done

But no relevant information was obtained.

But up in heaven

In the Dipper and Buffalo Palace

Investigation provided a clear result:

It was discovered that

Fourth Sister Zhang

Had left the Dipper and Buffalo Palace;

She descended to the mortal world

And arrived in the Eastern Capital

Now more than three years ago.

The Jade Emperor

Proclaimed an edict

Dispatching celestial troops,

They will descend

To arrest Fourth Sister

And she will return to the Heavenly Palace."

When the Humane Ancestor

Had heard these words

He was greatly frightened;

To his left and right

Civil and military officials

Shuddered with fear.

They all had thought 


\section{Fourth Sister Zhang}

Was some kind of demonic monster;

Nobody had known

That she actually was

The Jade Emperor's precious daughter!

This line of the story

We abandon for the moment

But instead we return

We can't go into detail now,

To Fourth Sister Zhang

And the way in which she wielded her weapons.

Now tell that Fourth Sister Zhang and her husband were resting in her embroidery room, when she suddenly felt her ears burning and her eyes twitching. When she silently calculated what this meant, she realized that this spelled trouble, so she promptly told her husband: "Today the Jade Emperor will dispatch heavenly troops to this place to arrest me and take me back to heaven." When Wenrui heard these words, he was frightened and panicked without end, but Fourth Sister said: "My darling, don't worry! If they come this way, I will inflict such a defeat on them that they will be left with not one piece of armor intact!"

As they were speaking, the heavenly troops arrived. Fourth Sister Zhang rose to her feet and went outside. When she lifted her head to have a look, she noticed the Water Dragon Crown Prince rising atop the clouds. Very soon he had arrived in front of her. The Crown Prince came forward, bowed to Fourth Sister, and said: "Princess, at the command of the Jade Emperor I have come here to invite you to return to heaven." When Fourth Sister heard this, she said: "If this is an invitation, then why have you come in full armor?" The Crown Prince replied: "If you reject the invitation, I'll be obliged to use force." Fourth Sister was filled by rage when she heard this, and she cursed him, saying: "You have some gall! If you have the ability to defeat me, I will go back." Indeed:

Fourth Sister reviled the Crown Prince;

The Crown Prince was filled with rage.

That Crown Prince

Hurriedly began to speak,

Furiously cursing Fourth Sister;

He cursed her:

"Fourth Sister Zhang

Listen carefully to my words.

Your father

The Jade Emperor

Is the ruler of the myriads of gods;

He administers the cosmos

Dominates heaven and earth

How awesome is his authority!

This very day 
I received from him

An edict to transmit to you:

Return with all speed

To the heavenly palace

And report to that worthy deity!"

When Fourth Sister Zhang

Had heard these words

A burning rage rose up in her heart:

"You and I

Will display our powers

To see who comes out on top!"

The Crown Prince was furious

And did not say any word

But with a shake of his body transformed,

He transformed himself

With one clap of thunder ${ }^{49}$

Promptly into a dragon made of fire.

He spat from his mouth

A huge glare of fire

But Fourth Sister Zhang

That rose up thousands of zhang,

When she saw that

Just gave a little snort in her nose.

Without any panic

She took out

She raised this

A magic object she carried on her person;

Treasure-collecting bowl

And flung it high into the empty sky.

Before too long

Black clouds assembled

And everything grew dark and blurry,

A great wind blew

Mixed with hailstones

While a heavy rain came pouring down.

That fire dragon

Seeing the situation below him

Beat his retreat with all possible speed,

And so that Crown Prince

Did not achieve victory

But instead nearly lost his life!

But from the other side

Came dashing out

Crown Prince Nezha,

He advanced and cursed

\footnotetext{
${ }^{49}$ Here the text reads $z i$ he lei 子和雷, which is difficult to make sense of.
} 
"You villainous young lady!"

And displayed his miraculous powers.

His transformation

Was nothing less than

A three-headed six-armed giant:

With his feet treading

On wheels of fire

He inspired more fear than a unicorn!

Fourth Sister Zhang

Never for one moment

Took serious notice of him,

She just loudly shouted:

"You brazen rogue

Don't try to show off your skills.

Never in my life

Did I treat you badly

So why do you try to bully me?"

Quickly she

Drew out a sword

Which she held up in her hands.

One turned to ten

One hundred to ten thousand

Each blade flashing a chilling light,

In the middle of the air

They all turned into

Flying blades ready to kill!

All aimed for

Li Nezha

Hacking in from all four sides,

So Li Nezha

Unable to resist

Hastily fled for his life.

But now arrived

Sun Wukong

The Great Sage Equal to Heaven,

Who loudly shouted:

"Fourth Sister Zhang

You damned hussy you!

You originally were

An immortal maiden

Covered in luxury and glory,

For what reason

Did you marry a mortal

And create such havoc in Bianliang?

You hurry up

And come with me 
To save me from

And return to the palaces of heaven,

Using my gold-hooped staff

To beat your body into fragments!"

Fourth Sister Zhang

Loudly shouted:

"You brazen monkey sprite!

You dare come

In front of my face

To spit out such wild words?

This very day

I'll make sure

You can't save your worthless life:

I'll flay your monkey skin,

Pull out your monkey tendons

And scoop out your monkey heart!"

Sun Wukong

Having been reviled this way

How could he put up with that?

Pulling out monkey hairs

He recited magic spells

And they all took on the shape of monkey gods.

Each and every one

Raised in his hands

Rushing forward

The same gold-hooped cudgel,

Each took aim

At Fourth Sister Zhang with his strokes.

Once Fourth Sister

Saw this situation

With a shake of her body she transformed,

She transformed herself

Into thousands of myriads

Of Fourth Sister body-doubles.

When Sun Wukong

Saw that his monkey hairs

Would be unable to achieve victory,

He drew in his

Gold-hooped staff

And hurriedly tried to escape.

Fourth Sister Zhang

With a faint smile

This young miss

Reviled him saying: "Monkey,

Has her own magic object

To thrash your monkey butt. 
When you go back to heaven,

Go to my father the Jade Emperor

And there tell him on my behalf:

Let him issue an edict

To the emperor on earth

To care lovingly for the common people;

Let men and women

Who love each other

Never have to suffer separation,

And may all the Half-City Wangs

And the Half-City Lis

Be completely wiped from the earth.

If my respected kind father

Will not promise this

The bond between father and daughter will be cut;

And if I

Fight my way to

The Divine Welkin Hall,

Within the heavenly palaces

All the various deities

Sun Wukong

Will be completely exterminated."

Pulled back men and horses

And hurriedly made his retreat;

He went up to heaven

And before the Jade Emperor

Transmitted the true state of affairs:

"Fourth Sister

Has superior skills

She's an expert in each and every art.

Even this Old Sun

Who was never defeated

Was unable to win victory.

She also wants you

Jade Emperor

To ensure that they

To protect and safeguard mortal men,

Enjoy the bliss of man and wife

And enjoy the favor of heaven."

Jade Emperor Zhang

Before he had heard all

Felt a towering rage blasting upward,

But the Queen-Mother

From one side

With wise words exhorted him:

"That little wench 
Possesses superior skills

It's your own fault

Who will be able to capture her?

For pampering her

So that she recognizes no authority at all!"

Jade Emperor Zhang

Then began to speak:

"You go and try to persuade her,

If you persuade her

To return to heaven

I will absolve her of any crime."

Now tell that Her Majesty the Queen Mother descended to the mortal world with the other six immortal maidens in order to exhort Fourth Sister to change her mind - but enough about that. Tell instead that Fourth Sister having won victory returned home. Only now did Cui Wenrui understand that she was the fourth daughter of His Majesty the Jade Emperor, and he was extraordinarily elated.

While the two of them were idly chatting, Fourth Sister Zhang suddenly saw that the gate of heaven had been opened and that an auspicious cloud was slowly moving in her direction. Fourth Sister knew that this was her mother coming to persuade her, so she explained the situation to Wenrui. When he heard this, his eyes brimmed over with tears, he found it so hard to part from his wife. Fourth Sister told him: "My darling, don't be so sad! I'll just take you along when I return to heaven today." Having said this, she took out her handkerchief, picked up the soul-capturing bottle and released the heroes and heroines of the Huyan and Yang families, and allowed each and every one of them to return to their homes. She then spread her handkerchief on the floor and gathered the treasure-collecting bowl and the other magic treasures in order to return them to Dragon King's Crown Prince.

Fourth Sister Zhang was just in the midst of packing up these things when Her Majesty the Queen Mother arrived. Fourth Sister went forward and paid her respects to her mother, and then greeted her sisters. After these rituals were over, the Queen Mother began to speak, saying: "You are an immortal maiden from heaven, so how could you marry a mere mortal? This mother of yours for your sake has been forced to bear so much bitterness! If you still remember the debt you owe for my bearing and raising you, come with me to the palaces of heaven. If you refuse to listen to your mother's advice, your father the king will issue his orders, and both mother and daughter will end up as beheaded ghosts!" When Fourth Sister had heard what her mother said, she replied: "It is not that I, your child, don't wish to obey you!" Indeed:

Fourth Sister had gone down on her own from the celestial palace, Because she longed for the inexhaustable joys of the human realm.

Fourth Sister Zhang

Cried out: "Dear Mother

Please carefully listen to my explanation.

It is not the case 
That I your child

Had no wish to be filial and obedient.

I was in that

Dipper and Buffalo Palace

Properly but idly sitting,

When I saw an aggrieved ether

Rise straight up on high

To the gate of the Dipper and Buffalo Palace!

That very moment

My passion was aroused

So on my own I descended to the mortal realm.

Now Cui Wenrui

Is on no account

A mere pawn with no name.

$\mathrm{He}$ is originally

From the upper world

A divine lad from the immortals.

He left the heavenly palace

Arrived in the mortal realm

And was reborn as a human being.

This day you,

My dear old mother

Have arrived here in person on earth,

The Cui mother and son

Should together with us

Return to the heavenly palaces above!"

The Queen Mother

Furrowed her brow in thought

But then put on a welcoming expression,

Fourth Sister Zhang

Seeing her mother had agreed,

Was now filled with a limitless joy!

The various female immortals

After hearing these words

Together set out on their way;

Riding auspicious clouds

They moved through the skies

And together returned to the palaces in heaven.

Before too long

They had arrived

By the banks of Clear Water River.

Fourth Sister Zhang

Suddenly thought

It would be good to wash out her stomach and guts.

But not being careful

She fell into the river 
And soaked all of her clothes,

Fourth Sister Zhang

After changing her clothes

Went to see the Jade Emperor.

Before too long

They had arrived at

Lifting her head

The Precious Hall of the Divine Welkin.

She saw her father the Jade Emperor

Seated high on his heavenly throne.

She walked forward

And paid her respects

To her father who had sired her,

The August Jade Emperor,

His fury not yet dissipated

Showed her a very stern face.

At this moment

Fourth Sister Zhang

Felt her heart jumping without cease,

But the Queen Mother

Immediately began to speak:

"You already promised to absolve any crime!"

When the Jade Emperor

Saw his darling daughter

In front of him once again,

And the Queen Mother

Reminded him of his promise

The rage in his heart was already pacified.

The Jade Emperor

Opening his mouth asked:

"Fourth Sister listen clearly to me now:

Why did you

All by yourself

On your own authority leave these palaces of heaven?"

Fourth Sister Zhang

Answered her father the emperor:

With a full confession of her adventures:

"On that day

Your child was just sitting

Right and proper as could be,

When an aggrieved ether

Blasted up as high as

The gate of the Dipper and Buffalo Palace,

Only then did I leave

For the world of mortals

To tie the bonds of matrimony. 


\section{Cui Wenrui}

That silly student

But he too

$$
\text { Had suffered his share of bitter pain, }
$$

Is from the upper world

And is a divinity in his own right."

Now tell that the Jade Emperor asked her: "What manner of upper world divinity is Cui Wenrui?" One of the divinities at his side promptly reported: "Cui Wenrui was originally a golden lad of Laozi's; his mother is the Auntie in the Moon." When the Jade Emperor heard this story, he said: "As you both are divinities of the superior world, you should all go back to your own palaces. From now on, without my express permission, no divinity is allowed to descend to the mortal world." All the divinities there present thanked him for his grace, and they all went back to their own palaces. Indeed:

All three members of this one family ascended to heaven, And each of them returned back to his or her own palace.

Having completed

This precious scroll

I leave it to later generations,

I admonish those in the world

Whether male or female

That Wang Qin

To listen to it very carefully.

Lusting for riches and sex

Did not die a good death,

Magistrate Zhang

Was executed

Listen to it with your ears

In front of the ornate palace gate.

Remember it in your heart

Never commit evil deeds;

On no account

Consider it an idle tale

You can ignore and put aside:

Those who harm others

Will precisely harm

In the end

None other than themselves,

No reward will be theirs

Only disasters will come to roost!

The copier of this scroll has had little education,

Those who read this scroll should keep this in mind.

There may be many wrong and faulty characters, 
So please correct them after you read this scroll. I had to spend much energy in copying the scroll, So when reciting this scroll, be very careful of it. 